\title{
Liver iron concentrations in sudden infant death syndrome
}

\author{
C A Moore, R Raha-Chowdhury, D G Fagan, M Worwood
}

First Community Health Trust, Stafford Central Clinic, Stafford

C A Moore

\section{Department of}

Haematology,

University of Wales

College of Medicine, Cardiff

R Raha-Chowdhury

$M$ Worwood

Department of

Histopathology,

University Hospital,

Nottingham

D G Fagan

Correspondence to Dr Mark Worwood,

Department of Haematology, University of Wales College of Medicine, Heath Park,

Cardiff CF4 4XN.

Accepted 1 January 1994

\begin{abstract}
To determine the biological significance of high concentrations of non-haem iron in the livers of infants dying from sudden infant death syndrome (SIDS), liver samples were obtained at necropsy from 66 infants who died from SIDS and 28 control infants who died before 2.5 years of age. All were full term deliveries. Liver iron concentrations decreased rapidly with age in the two groups. Liver iron concentrations in the SIDS infants and controls were compared for those infants who died between 1 month and 1 year of age. The median liver iron concentration in the SIDS infants was $296 \mu \mathrm{g} / \mathrm{g}$ wet weight; significantly higher than the median of $105 \mu \mathrm{g} / \mathrm{g}$ in controls. There was an inverse relation between iron concentration and age in the two groups, but an analysis of covariance confirmed the significantly lower values in controls. The frequency $(22 \%)$ of HLA-A3 in SIDS infants was similar to that expected for the United Kingdom population (25\%) and does not implicate the gene for haemochromatosis as a cause of high liver iron concentrations.

These findings show that the peak incidence of SIDS occurs when mean concentrations of iron in liver tissue are higher than at any other time of life. Although a primary causal connection seems unlikely, high tissue iron concentrations may lower resistance to infection and enhance free radical formation, leading to tissue damage.

(Arch Dis Child 1994; 70: 295-298)
\end{abstract}

Causes of death in control subjects dying from 1 month to 1 year of age

\begin{tabular}{|c|c|c|c|c|}
\hline $\begin{array}{l}\text { Patient } \\
\text { No }\end{array}$ & $\begin{array}{l}\text { Sex } \\
(F / M)\end{array}$ & $\begin{array}{l}P C A \\
\text { (weeks) }\end{array}$ & Cause of death & $\begin{array}{l}\text { Liver iron } \\
(\mu g / g \text { wet } \\
\text { weight })\end{array}$ \\
\hline $\begin{array}{l}1 \\
2\end{array}$ & $\begin{array}{l}\mathbf{F} \\
\mathbf{F}\end{array}$ & $\begin{array}{l}88 \\
92\end{array}$ & $\begin{array}{l}\text { Freshwater drowning; previously well } \\
\text { Hypoxia, laryngeal polyposis, presumed viral } \\
\text { infection several weeks previously }\end{array}$ & $\begin{array}{l}71 \\
72\end{array}$ \\
\hline $\begin{array}{l}3 \\
4\end{array}$ & $\begin{array}{l}\mathbf{M} \\
\mathrm{F}\end{array}$ & $\begin{array}{l}88 \\
83\end{array}$ & $\begin{array}{l}\text { Asphyxia, foreign body; previously well } \\
\text { Acute asphyxia, massive inhalation of gastric } \\
\text { contents; previously trapped between mattress and } \\
\text { cot frame }\end{array}$ & $\begin{array}{r}58 \\
105\end{array}$ \\
\hline $\begin{array}{l}5 \\
6 \\
7 \\
8 \\
9\end{array}$ & $\begin{array}{l}\mathrm{M} \\
\mathrm{F} \\
\mathrm{M} \\
\mathrm{F} \\
\mathrm{M}\end{array}$ & $\begin{array}{l}79 \\
54 \\
59 \\
50 \\
58\end{array}$ & $\begin{array}{l}\text { Acute meningococcal meningitis } \\
\text { Cerebral oedema, convulsions } \\
\text { Intussusception } \\
\text { RSV pneumonitis } \\
\text { Congenital heart defect. Necrotising tracheo- } \\
\text { bronchitis and massive pulmonary haemorrhage }\end{array}$ & $\begin{array}{r}64 \\
100 \\
220 \\
284 \\
132\end{array}$ \\
\hline 10 & $\mathbf{M}$ & 55 & $\begin{array}{l}\text { Down's syndrome. Pulmonary hypertension, } \\
\text { atrioventricular canal defect }\end{array}$ & 30 \\
\hline $\begin{array}{l}11 \\
12 \\
13 \\
14 \\
15\end{array}$ & $\begin{array}{l}\mathbf{M} \\
\mathbf{M} \\
\mathbf{M} \\
\mathbf{F}\end{array}$ & $\begin{array}{l}66 \\
74 \\
65 \\
69 \\
44\end{array}$ & $\begin{array}{l}\text { Streptococcal septicaemia } \\
\text { Congenital heart disease; right ventricular failure } \\
\text { RSV pneumonitis and bronchopneumonia } \\
\text { Endocardial fibroelastosis (sudden death) } \\
\text { Esherichia coli septicaemia and meningitis }\end{array}$ & $\begin{array}{r}193 \\
66 \\
105 \\
258 \\
418\end{array}$ \\
\hline
\end{tabular}

$\mathrm{PCA}=$ postconceptional age; $\mathrm{RSV}=$ respiratory syncytial virus.
The peak incidence of the sudden infant death syndrome (SIDS) is between 2 and 4 months of age ${ }^{1}$ when mean blood haemoglobin concentrations are lower ${ }^{2}$ and levels of storage iron may be higher than at any other time of life. ${ }^{3}$ A preliminary study showed much higher concentrations of iron in the livers of victims of SIDS than in historical controls, an inverse relation with age, and extremely high ferritin concentrations in cardiac blood at necropsy, suggesting that high concentrations of tissue iron may be implicated in SIDS. ${ }^{4}$ Other workers have also found high concentrations of iron in the livers of victims of SIDS and a relation with age. ${ }^{5-6}$

There is increasing evidence of an association between high concentrations of iron in tissues and disease, including infection, neoplasia, and ischaemic heart disease. ${ }^{7}$ Although the pathology of SIDS is heterogenous, infection, hypoxia, and thermal stress are all implicated ${ }^{8}$ and iron may exacerbate the deleterious effects of each of these by enhancing free radical formation. ${ }^{9}$

We examine here the relation between hepatic iron concentrations and age at death in infants to determine whether iron concentrations are higher in those dying unexpectedly and without explanation (SIDS) than in infants dying as a result of an accident or in hospital. High iron concentrations may be associated with the gene for hereditary haemochromatosis, ${ }^{10}$ a common HLA linked disorder in Europeans, though there have been no reported studies of iron metabolism in HLA linked haemochromatosis in infancy. To determine whether the presence of the haemochromatosis gene is associated with high concentrations of iron in the liver we determined the occurrence of the HLA-A3 antigen, a marker for the gene, in infants dying from SIDS.

\section{Methods}

SAMPLES

Samples of liver tissue were obtained at necropsy from 63 full term infants (36 weeks' gestation or more) dying from SIDS and 15 full term controls who had died from a variety of causes between the ages of 1 and 12 months (table 1). The cause of death was described as SIDS after full examination by the pathologist at the four centres and in accordance with the definition given by Beckwith. ${ }^{11}$ No infant with inherited anaemia or who received a blood transfusion was included. Samples were also obtained from 16 infants who had died between birth and 1 month of age or between 1 year and 2.5 years (including four cases of SIDS outside the 1 month to 1 year range) to 


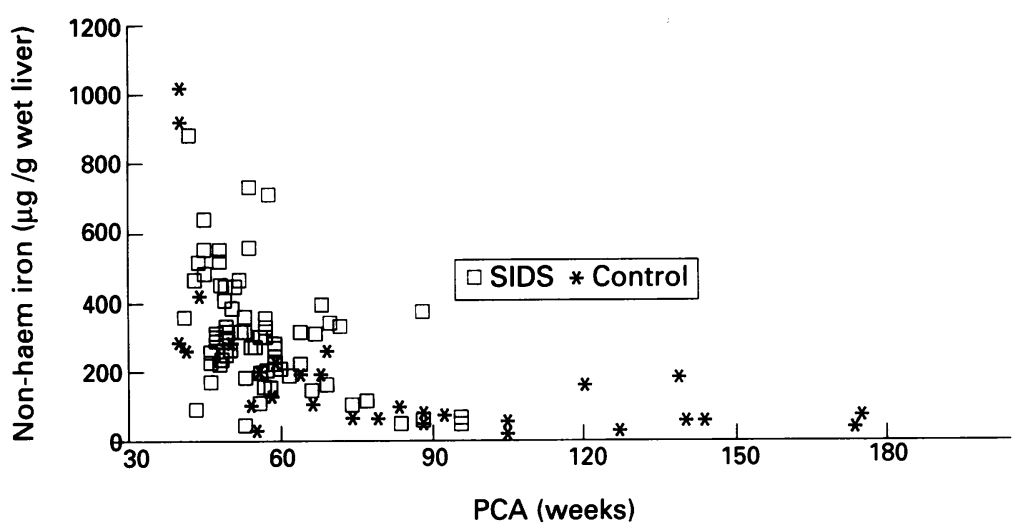

Figure 1 Liver iron concentrations in full term infants. $P C A=$ postconceptional age.

establish the relation between concentrations of iron in the liver and age. These infants were excluded from the comparison of SIDS and control cases.

Samples were collected from four centres in the United Kingdom: West Midlands (Wolverhampton, Birmingham, Stafford), Cardiff, Nottingham, and Edinburgh, but all the measurements were made in Cardiff. Samples were stored at $-20^{\circ} \mathrm{C}$ for up to two years before testing. Liver samples were stored at $-70^{\circ} \mathrm{C}$ in Nottingham.

\section{ASSAYS}

Non-haem iron concentrations in the liver

The iron content of liver tissue was determined by the method of Torrance and Bothwell ${ }^{12}$ using ferrozine as the chromogen. Results are expressed as $\mu \mathrm{g}$ iron/g wet weight. In some instances iron was also determined by homogenising a small piece of liver (about $0.05 \mathrm{~g}$ ) in $1 \mathrm{ml} 0.9 \%$ sodium chloride using a glass microhomogeniser. The iron content was determined as described by Worwood and Darke ${ }^{13}$ except that the homogenate was incubated with the protein precipitant solution at $56^{\circ} \mathrm{C}$ overnight. The protein concentration of the homogenate was determined by the method of Lowry et al ${ }^{14}$ with bovine serum albumin as standard and the iron concentration was expressed as $\mu \mathrm{g}$ iron/mg protein.

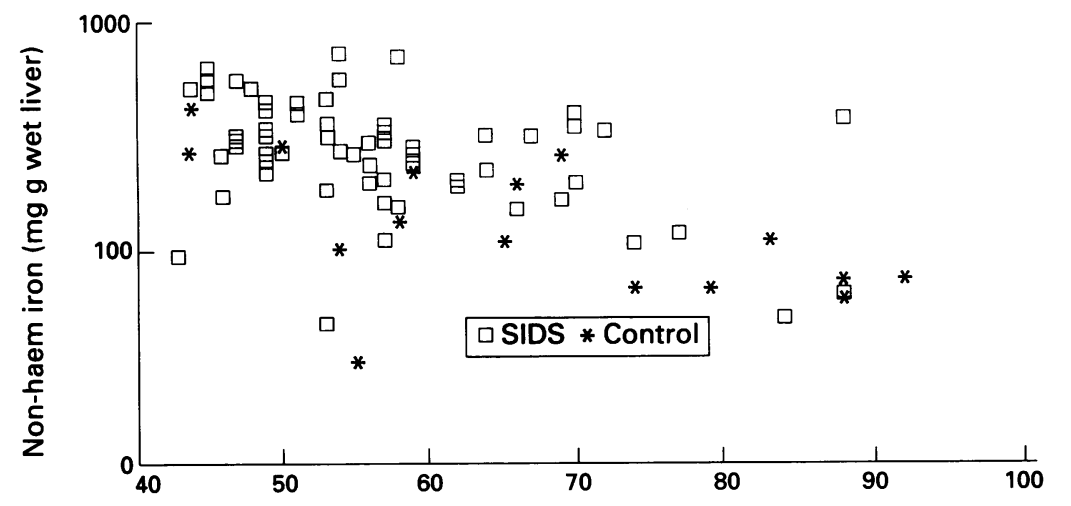

PCA (weeks)

Figure 2 Liver iron concentrations in full term infants dying from 1 month to 1 year of Figure 2 Liver iron concentrations in full term infants dying from 15 controls the regression equation is $\log _{10}$ iron $=3.04-0.0109 \mathrm{PCA}$; $r=-0.443 ; p<0.001$. For the 63 infants dying from SIDS the regression equation is $\log _{10}$ iron=2.80-0.0109 PCA; $r=-0.528 ; p=0.043$. $P C A=$ postconceptional age.
HLA genotyping

DNA was prepared ${ }^{15}$ from the liver or blood of 23 victims of SIDS and cut with the restriction enzyme TaqI. After Southern blotting the DNA was hybridised to pHLA-A, an HLA-A specific probe, and the presence of HLA-A3 deduced from the restriction fragment pattern. ${ }^{16}$

\section{Results}

IRON CONCENTRATIONS IN THE LIVER

Initially concentrations of iron in liver tissue were determined by homogenising the tissue and relating the iron concentration of the homogenate to the protein concentration. Comparison with the method of Bothwell and Torrance ${ }^{12}$ showed a good correlation (33 SIDS, seven controls; $r=0 \cdot 90$ ), however, and all results are reported as $\mu \mathrm{g}$ iron/g wet weight using the latter method. Figure 1 shows concentrations of iron in liver tissue for 66 infants who died from SIDS and for 28 controls dying up to the age of 2.5 years. Iron concentrations decreased with age for the two groups and to compare concentrations of iron in liver tissue in the cases and controls, only infants dying from 1 month to 1 year of age were included. There were 63 cases of SIDS and 15 controls (details of the controls are given in the table).

The median non-haem iron concentration in liver tissue in the 63 infants dying from SIDS was $296 \mu \mathrm{g} / \mathrm{g}$ wet weight, significantly higher than the median of $105 \mu \mathrm{g} / \mathrm{g}$ wet weight in 15 control infants (two sample Wilcoxon rank sum test; $p=0 \cdot 002$ ). There was no significant difference in the median iron concentration between boys and girls dying from SIDS $(296 \mu \mathrm{g} / \mathrm{g}$ in $25 \mathrm{girls} ; 296 \mu \mathrm{g} / \mathrm{g}$ in 37 boys; $\mathrm{H}=0.13 ; \mathrm{p}=0.71$; Kruskal-Wallis test) nor between the median values for the different centres. As the mean postconceptional age of the controls (PCA, 68 weeks) was greater than that for infants dying from SIDS (PCA 57 weeks) and changes in age affect the mean concentration of iron in liver tissue, an analysis of covariance $^{17}$ was carried out. The correlation between iron concentration and age is non-linear and iron concentrations were transformed to logarithms for this comparison. Figure 2 gives the regression lines. The slope of each line is the same but the analysis of covariance shows that the regression lines are significantly different $(t=-3 \cdot 23$, for $75 \mathrm{df}$; $\mathrm{p}=<0.01)$.

\section{HLA GENOTYPING}

In the 23 infants examined who had died from SIDS, five (22\%) were HLA-A3 positive. Infants who were HLA-A3 positive did not have higher liver iron concentrations than those who were HLA-A3 negative. In a population homozygous for hereditary haemochromatosis ${ }^{13}$ the incidence of HLA-A3 should approach $75 \%$, in a group of heterozygotes $57 \%$, with a frequency in the general population in the United Kingdom of about $25 \%$. We have not yet 
found evidence to suggest that inheritance of the haemochromatosis gene is associated with high iron stores or is a risk factor for SIDS.

\section{Discussion}

We found higher concentrations of iron in the liver tissue of infants dying from SIDS than in control infants. The correlation between iron concentrations related to protein content and the corresponding values per gram wet weight in the two groups indicates that iron concentrations are not influenced by variations in fat or water content, which may affect the livers of control infants. The decrease in hepatic iron concentration with age has been reported previously, but premature and full term births were not distinguished.5 ${ }^{5}$ The influence of gestational age and prematurity on liver iron stores may be important, particularly as there is a high incidence of SIDS in preterm infants. ${ }^{1}$ In full term infants iron concentrations in the bone marrow are high at birth but in preterm infants bone marrow iron stores are low at birth and reach high concentrations after one month..$^{18}$ In five preterm infants dying from SIDS (Nottingham), however, the mean iron concentrations in the liver were within the normal range found in full term victims of SIDS (mean 260 , range $159-421 \mu \mathrm{g} / \mathrm{g}$ wet weight; mean PCA 49 (42-55) weeks).

We also measured blood ferritin concentrations at necropsy in cases and controls and found extremely high concentrations. The median concentrations were $22500 \mu \mathrm{g} / \mathrm{l}$ in infants dying from SIDS and $6900 \mu \mathrm{g} / \mathrm{l}$ in seven controls. Blood ferritin concentrations increase rapidly after death but are related to iron concentrations in the liver. This extreme ferritinaemia appears to be characteristic of infancy and may reflect high concentrations of iron in phagocytic cells. ${ }^{18}$ These findings will be reported in detail elsewhere.

In full term infants up to 6 months of age iron concentrations in the liver are often high and sometimes within the range taken to be diagnostic for hereditary haemochromatosis in adults. ${ }^{19} \mathrm{We}$ have shown that such concentrations are not likely to be due to the presence of the gene for haemochromatosis.

High concentrations of tissue iron may be acquired prenatally or postnatally. The mother's level of storage iron does not appear to be an important factor in determining fetal iron stores ${ }^{3}$ but infants born to mothers receiving iron treatment by mouth may have higher concentrations of ferritin in cord blood. ${ }^{20} \mathrm{We}$ are currently measuring ferritin concentrations in blood spots collected on Guthrie cards during the first week of life to determine whether infants who subsequently die from SIDS have higher concentrations of ferritin at birth.

Late clamping of the umbilical cord causes a significant increase in the infant's red cell mass $^{21}$ which may be highly beneficial in preterm infants. The high rate of haemoglobin breakdown and relatively low rates of synthesis in the first weeks of life result in high concentrations of storage iron in the cells of the reticuloendothelial system. ${ }^{18}$ Increased $\mathrm{HbF}$ concentrations have been found in victims of SIDS. ${ }^{22}$ These infants may have higher tissue non-haem iron concentrations if there is a delay in initiating adult haemoglobin synthesis.

If excess iron is acquired postnatally, then dietary intake may be an important determinant of tissue concentrations. There is some evidence that infants not supplemented with iron are less likely to die from SIDS $^{23}$ and a multicentre postneonatal mortality survey found that more victims of SIDS had received drugs containing iron before death than infants dying from other disorders. ${ }^{24}$ The low incidence of SIDS among Asian infants in Britain may be related to their high incidence of iron deficiency. ${ }^{4}$

There is now overwhelming evidence that free radicals play a major part in mediating a wide variety of human disorders and the importance of iron in enhancing free radical damage is well established. ${ }^{9}$ Stress factors associated with SIDS including infection, hypothermia, and hypoxia are all associated with the generation of superoxide and hydrogen peroxide. Ferrous ions may be released from ferritin by reduction or in the presence of superoxide $^{25}$ and hydrogen peroxide reacts with ferrous ions to produce toxic hydroxyl radicals (Fenton reaction). ${ }^{10}$

Maternal cigarette smoking has been associated with SIDS. In infants who are thus passive smokers, the release of oxidants by activated inflammatory cells together with the oxidants in cigarette smoke itself may injure the respiratory epithelium. ${ }^{26}$

If there are insufficient protective antioxidants such as vitamin $E$ and selenium, excess iron could result in a fatal imbalance between oxidants and antioxidants, ${ }^{5}$ resulting in peroxidation damage to lipid membranes, particularly in the pulmonary capillary membranes, causing the flooding of alveoli characteristically seen in SIDS. ${ }^{9}$

Although high tissue iron concentrations lower the resistance to infection and increase the susceptibility to tissue damage, we cannot yet say that the high concentrations of storage iron found in victims of SIDS are outside the normal range for live infants in this age group, nor that iron is causatively implicated in SIDS. Sudden infant death syndrome, however, occurs at an age when mean tissue iron concentrations are higher than at any other time of life. ${ }^{3}$ Such high iron concentrations may play a part in determining whether or not an infant survives a period of stress brought on by hypoxia or high temperature.

If further studies establish high tissue concentrations of iron as a contributory factor in SIDS, there will be an urgent need for the reappraisal of iron supplementation in infancy.

This work has been supported by The Foundation for the Study of Infant Deaths. We are most grateful to Dr S P Ward and Dr A Jacobs (New Cross Hospital, Wolverhampton), Dr J W A Jacobs (New Cross Hospital, Wolverhampton), Dr J W Keeling (Royal Hospital for Sick Children, Edinburgh), Dr V
Suarez (Stafford), Dr T P Rollason (Birmingham Maternity Suarez (Stafford), Dr T P Rollason (Birmingham Maternity
Hospital), and Dr G M Vujanic (department of pathology, Hospital), and Dr G M Vujanic (department of pathology,
University of Wales College of Medicine) for providing postmortem samples. 
1 Gibson AAM. Current epidemiology of SIDS. $f$ Clin Pathol 1992; 45: 7-10.

2 Oski FA. The erythrocyte and its disorders. In: Nathan DG, Oski FA, eds. Haematology infancy and childhood. 4th Ed. Philadelphia: W B Saunders, 1993: 18-43.

3 Worwood M. Serum ferritin. In: Jacobs A, Worwood M, eds. Iron in biochemistry and medicine II. London: eds. Iron in biochemistry and

4 Academic Press, 1980 . Worwood M. Iron and the sudden infant death syndrome. BMF 1989; 298: 1248.

5 Money DFL. Vitamin E, selenium, iron and vitamin A content of livers from sudden infant death syndrome cases and control children: interrelations and possible significance. $N Z$ f Sci 1989; 21: 41-55.

6 Steele RJ, Fogery AC, Willox ME, Clancy SL. Metal content of the liver in sudden infant death syndrome. Australian Paediatric fournal 1984; 20: 141-2.

7 Weinberg ED. Cellular iron metabolism in health and disease Drug Metab Rev 1990; 22: 531-79.

8 Berry PJ. Pathological findings in SIDS. 7 Clin Pathol 1992; 45: $11-6$.

9 Halliwell B, Gutteridge JMC. Free radicals in biology and medicine. Oxford: Clarendon Press, 1989.

10 Bothwell TH, Charlton RW, Motulsky AG. Hemochromatosis. In: Scriver CR, Beaudet AL, Sly WS Valle D, eds. 6th Ed. New York: McGraw-Hill, 1989: 1433-62.

11 Beckwith JB. Observations on the pathological anatomy of the sudden infant death syndrome. In: Bergman B, Beckwith JB, Ray CG, eds. Sudden infant death syndrome. Proceedings of the Second International Conference on the Causes of Sudden Death in Infants. Seattle: University of Washington, 1970 .

12 Torance ID Bothwell TH. Tissue iron stores. In: Cook JD, ed. Iron. New York: Churchill Livingstone, 1980: 90-115. (Methods in hematology; Vol 1.)

13 Worwood M, Darke C. Serum ferritin, blood donation, iron stores and haemochromatosis. Transfusion Medicine 1993 3: 21-8.
14 Lowry OH, Rosebrough NJ, Farr AL, Randall RJ. Protein measurement with the Folin phenol reagent. $\mathcal{F}$ Biol Chem 1951; 193: 265-75.

15 Miller SA, Dykes DA, Plesky HF. A simple salting out procedure for extracting DNA from human nucleated cells. Nucleic Acids Res 1988; 16: 1215

16 Cragg SJ, Darke C, Worwood M. HIA class I and H ferritin gene polymorphisms in normal subjects and patients with haemochromatosis. Hum Genet 1988; 80: 63-8.

17 Armitage P, Berry G. Statistical methods in medical research. 2nd Ed. Oxford: Blackwell Scientific, 1987.

18 Seip M, Halvorsen S. Erythrocyte production and iron during the first months of life. Acta Paediatr 1956; 45: 600-17.

19 Bassett ML Halliday JW, Ferris RA, Powell LW. Diagnosis of haemochromatosis in young subjects: predictive accuracy of biochemical screening tests. Gastroenterology 1984; 87: 628-33.

20 Barrada M, Pateisky N, Schatten C, et al. Ferritin speigel von Neugeborenen nach prapartaler Eisenmedikation. Geburtshilfe Frauenheilkd 1991; 51: 366-8.

21 Kinmond S, Aitchison TC, Hollands BM, Jones JG, Turner TL, Wardrop CAJ. Umbilical cord clamping and preterm infants: a randomised trial. BMF 1993; 306: 172-5.

22 infants: a rand Walker A. Haemoglobin F levels in sudden infant deaths. Br 7 Haematol 1992; 82: 422-30.

23 Money DFL. Feeding and the sudden infant death syndrome: classification of 224 New Zealand cases by milk food given. New Zealand fournal of Science 1978; 21 547-51.

24 Knowelden J, Keeling J, Nicholl J. A multicentre study of post-neonatal mortality. London: Department of Health and Social Security, 1985.

25 Monteiro HP, Winterbourn CC. The superoxide dependent transfer of iron from ferritin to transferrin and lactoferrin. Biochem 7 1988; 256: 923-8.

26 Crystal RG. Oxidants and respiratory tract epithelial injury: pathogenesis and strategies for therapeutic intervention. Am fMed 1991; 91 (suppl 3C): 39S-44S. 